\title{
Immunochemical Characterization of Acacia Pollen Allergens and Evaluation of Cross-Reactivity Pattern with the Common Allergenic Pollens
}

\author{
Mohammad-Hosein Shamsbiranvand, ${ }^{1,2}$ Ali Khodadadi, ${ }^{1,2}$ \\ Mohammad-Ali Assarehzadegan, ${ }^{2}$ Seyed Hamid Borsi, ${ }^{3}$ and Akram Amini ${ }^{2}$ \\ ${ }^{1}$ Cancer Research Center of Ahvaz Jundishapur University of Medical Sciences, Ahvaz, Iran \\ ${ }^{2}$ Department of Immunology, Faculty of Medicine, Ahvaz Jundishapur University of Medical Sciences, Ahvaz 6135715794, Iran \\ ${ }^{3}$ Department of Internal Medicine, Faculty of Medicine, Ahvaz Jundishapur University of Medical Sciences, Ahvaz, Iran
}

Correspondence should be addressed to Mohammad-Ali Assarehzadegan; assarehma@gmail.com

Received 21 January 2014; Accepted 17 March 2014; Published 18 May 2014

Academic Editor: William E. Berger

Copyright (c) 2014 Mohammad-Hosein Shamsbiranvand et al. This is an open access article distributed under the Creative Commons Attribution License, which permits unrestricted use, distribution, and reproduction in any medium, provided the original work is properly cited.

\begin{abstract}
Pollen from the Acacia has been reported as an important source of pollinosis in tropical and subtropical regions of the world. The aim of this study was to characterize the IgE binding protein of Acacia farnesiana pollen extract and evaluate cross-reactivity with the most allergenic pollens. In this study, pollen extract was fractionated by SDS-PAGE and the allergenic profile was determined by IgEimmunoblotting and specific ELISA using forty-two Acacia allergic patients. Potential cross-reactivity among Acacia and selected allergenic plants was evaluated with ELISA and immunoblotting inhibition experiments. There were several resolved protein fractions on SDS-PAGE which ranged from 12 to $85 \mathrm{kDa}$. Several allergenic protein bands with molecular weights approximately between 12 and $85 \mathrm{kDa}$ were recognized by IgE-specific antibodies from Acacia allergic patients in the immunoblot assay. The inhibition by the Prosopis juliflora pollen extract was more than those by other pollen extracts. Moreover, the wheal diameters generated by the Acacia pollen extract were highly correlated with those of $P$. juliflora pollen extracts. The findings suggest that several proteins such as $15,23,45$, and $50 \mathrm{kDa}$ proteins could be used as diagnostic and therapeutic reagents for patients allergic to A. farnesiana and P. juliflora.
\end{abstract}

\section{Introduction}

Acacia farnesiana (Vachellia farnesiana), a member of the Fabaceae family, is common throughout tropical and subtropical regions of Asia, Africa, Australia, and America with hot and humid climates, where it is planted as a shade and/or ornamental tree or for binding sand $[1,2]$. Pollens from the Fabaceae family have been reported as an important source of pollinosis in the United States, European countries, and Asia [1-3]. Moreover, the inhalation of A. farnesiana pollen is one of the main causes of respiratory allergic diseases in semiarid countries such as Iran, Saudi Arabia, and the United Arab Emirates, where the frequency of sensitization ranges from $25 \%$ to $48 \%[2,4-7]$.
Howlett et al. reported a high level of cross-reactivity between Acacia (wattle) and Lolium perenne (rye grass) pollen using the radioallergosorbent test (RAST) [8]. The results showed that IgE molecules which bound to Acacia pollen proteins also bound to $L$. perenne pollen extracts. In spite of a high rate of sensitization to Acacia pollen in Iran and neighboring countries, to our knowledge, there are few studies about the characterization of A. farnesiana pollen extract, and cross-reactivity of this plant with the five most allergenic pollens in arid and semiarid areas (Prosopis juliflora, Salsola kali, Amaranthus retroflexus, Chenopodium album, and Kochia scoparia) is not well documented $[2,5,9,10]$.

The recognition of allergenic components of pollens is essential for component-resolved diagnosis, the design 
of patient-specific immunotherapy, and the explanation of sensitization mechanisms to various allergens [11, 12]. In this study, we evaluate proteins of Acacia pollen extract which are specifically reactive to the immunoglobulin $\mathrm{E}$ ( $\operatorname{IgE})$ of pollen-allergic patients and the IgE cross-reactivity among $A$. farnesiana and the selected plants using in vivo and in vitro assessments.

\section{Materials and Methods}

2.1. Preparation of Extract. Polleniferous materials were collected from A. farnesiana's flowers during February-May throughout Ahvaz city, a tropical region in southwest Iran with a tropical climate and a population of more than 1.4 million [2].

Collection and processing of pollen materials was done carefully by trained pollen collectors. Pollen grains were separated by passing the dried materials through different sieves (100, 200, and 300 meshes) successively. The final fine powder was subjected to a purity check for pollen content using a microscope. Pollen materials with more than $95 \%$ pollen and less than $5 \%$ floral parts of the same plant were taken for antigen extraction.

Pollen materials were defatted using repeated changes of diethyl ether. Pollen was extracted as described previously [10]. In brief, two grams of pollen was mixed with $10 \mathrm{~mL}$ phosphate-buffered saline (PBS) $0.01 \mathrm{M}(\mathrm{pH} 7.4$ ) by continuous stirring for $18 \mathrm{~h}$ at $4^{\circ} \mathrm{C}$. The extract was centrifuged at $16,000 \mathrm{~g}$, filtered through a $0.22 \mu \mathrm{m}$ membrane under sterile conditions, and dialyzed against $10 \mathrm{mM}$ phosphate buffer. The extract was then freeze-dried. The protein content of the extract was measured by Bradford's method [13].

2.2. Patients and Skin Prick Test. Forty-two respiratory allergic patients were enrolled in this study presented to the Immunology and Allergy Department of Ahvaz Jundishapur University of Medical Sciences. The patients were asked to complete a detailed questionnaire. They were considered as having a history of allergy if they reported at least one eye, nasal, or respiratory symptom to common allergens such as house dust, domestic animals, food, or pollen. The patients were also evaluated by a clinical examination and a skin prick test (SPT) with common aeroallergens. Ten healthy subjects who presented negative SPTs and no specific $\operatorname{IgE}$ to the $A$. farnesiana pollen extract were assigned as negative controls. The human ethics committee of the institute approved the study protocol with informed written consent from each patient.

Skin prick tests were performed by an experienced nurse under physician's supervision. In this test, A. farnesiana and the most allergenic pollen extracts (Prosopis juliflora, Salsola kali, Amaranthus retroflexus, Chenopodium album, and Kochia scoparia) were put on the patients' inner forearms and irritation of the epidermis was caused by prick method. The result was observed after 15 minutes. Next, the mean diameter of wheal reaction in every patient was measured and compared with negative (glycerol saline) and positive (histamine, $10 \mathrm{mg} / \mathrm{mL}$ ) controls. Patients with a wheal diameter $>3 \mathrm{~mm}$ were considered positive compared to negative and positive controls and were asked to donate a serum sample. Serum samples of patients were stored at $-20^{\circ} \mathrm{C}$ before use.

2.3. Enzyme-Linked Immunosorbent Assays (ELISAs). Total serum IgE levels were measured by means of a commercially available ELISA kit according to the manufacturer's instructions (Radim, Italy).

To measure the levels of specific IgE to A. farnesiana pollen in patients' sera, an indirect ELISA was developed as described earlier [14]. Briefly, $0.2 \mu \mathrm{g}$ of $A$. farnesiana pollen extract in $100 \mu \mathrm{L}$ carbonate buffer $\left(15 \mathrm{mM} \mathrm{Na}_{2} \mathrm{CO}_{3}\right.$ and $35 \mathrm{mM} \mathrm{NaHCO}_{3}, \mathrm{pH}$ 9.6) was incubated at $4^{\circ} \mathrm{C}$ overnight per well of a 96-well microtiter plate (Nunc MaxiSorp, Denmark). Each well was then blocked for $1 \mathrm{~h}$ at $37^{\circ} \mathrm{C}$ with $150 \mu \mathrm{L}$ of $2 \% \mathrm{BSA}$ in PBS followed by incubation for $3 \mathrm{~h}$ with $100 \mu \mathrm{L}$ of serum at room temperature with shaking. Each well was then incubated for $2 \mathrm{~h}$ at room temperature with 1:1000 dilution of biotinylated goat anti-human IgE antibody (Nordic Immunology Co., Netherlands) in 1\% BSA. Each incubation step was followed by five washes with PBS-T (PBS containing $0.05 \%$ Tween 20 ). Wells were added by $100 \mu \mathrm{L}$ of a 1:5000 dilution of horseradish peroxidase-conjugated streptavidin (Bio-Rad, USA). Following five washes, $100 \mu \mathrm{L}$ of chromogenic substrate was added to each well and the plate was incubated for $15 \mathrm{~min}$ in the dark. The plate was read at $450 \mathrm{~nm}$ with an ELISA reader. Optical density $\left(\mathrm{OD}_{450}\right)$ greater than four times the median values of the negative controls was considered to be positive.

2.4. Total Extract Preparation. Pollens from $P$. juliflora (mesquite), S. kali, A. retroflexus, C. album, and K. scoparia were prepared from polleniferous materials and then their extracts were prepared as described above [10]. The protein content of each extract was then determined using Bradford's method [13].

2.5. SDS-PAGE and IgE-Immunoblotting. Sodium dodecyl sulfate polyacrylamide gel electrophoresis (SDS-PAGE) of Acacia pollen extract $(60 \mu \mathrm{g})$ was performed according to Laemmli [15] using $12.5 \%$ or $15 \%$ acrylamide separation gels under reducing and nonreducing conditions. Reducing and nonreducing sample buffers were the same except that the final reducing sample buffer contained 5\% (vol/vol) 2mercaptoethanol (2-ME). Separated protein bands from the electrophoresis of $A$. farnesiana pollen extract were electrotransferred to polyvinylidene difluoride (PVDF) membranes (Immobilon P, Millipore Corp., Bedford, MA, US), as described earlier [10]. In brief, after washing and blocking, membranes were incubated with a $1 / 5$ dilution of serum pool or individual sera from patients with $A$. farnesiana allergy or with control sera (1:5 dilutions). Biotinylated anti-human IgE (Nordic Immunology Co., Netherlands) (1:500 v/v in 1\% BSA) was added to the blotted membrane strips and incubated for $2 \mathrm{~h}$ at room temperature. The unbound antibodies were removed from blots by washing with PBS and followed by incubation with $1: 10000 \mathrm{v} / \mathrm{v}$ in BSA1\% HRP-linked streptavidin (Sigma-Aldrich, USA) for $2 \mathrm{~h}$ at room temperature. The bound enzymatic activity of horseradish peroxidase was 


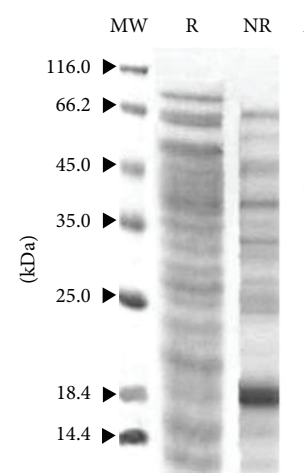

(a)

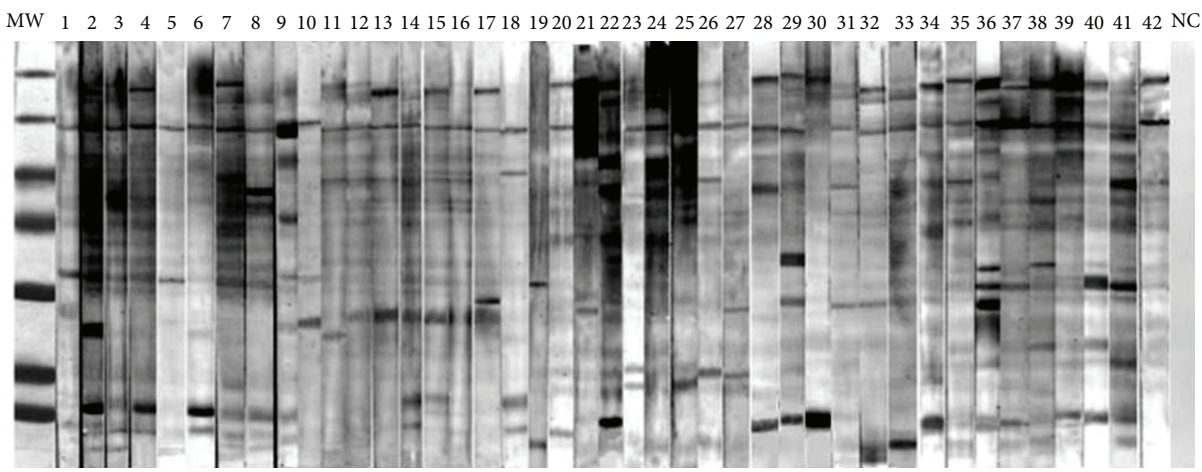

(b)

FIGURE 1: (a) Coomassie Brilliant Blue stained SDS-PAGE of the crude extract of A. farnesiana pollen in reducing and nonreducing conditions on $12.5 \%$ acrylamide gel. Lane MW, molecular weight marker (Fermentas, Lithuania); R, reducing condition; NR, nonreducing condition. (b) Immunoblotting of Acacia pollen extract (with reducing SDS-PAGE). Each strip was first blotted with Acacia pollen extract. All strips were then incubated with allergic patients' sera and detected for IgE reactive protein bands. Lane MW, low molecular weight. NC, negative control.

detected by high-sensitivity liquid diaminobenzidine (Liquid $\mathrm{DAB}^{+}$) chromogen (DAKO, Denmark).

2.6. ELISA Inhibition. ELISA inhibition assays were performed as described above, except that a pooled serum $(1: 2$ $\mathrm{v} / \mathrm{v}$ ) from A. farnesiana allergic patients (numbers 2, 7, 21, 24, and 36) was preincubated for one hour at room temperature with either $1000,100,10,1,0.1$, or $0.01 \mu \mathrm{g}$ of the selected pollen extract (including $P$. juliflora, S. kali, A. retroflexus, $C$. album, and K. scoparia) as inhibitors or with BSA as a negative control. Percentage of inhibition was calculated using the following formula: (OD of sample without inhibitor - OD of sample with inhibitor/OD of sample without inhibitor $) \times 100$.

2.7. IgE-Immunoblotting Inhibition. To study the crossreactivity between $A$. farnesiana pollen and selected allergenic plants, the IgE-immunoblot inhibition experiment was performed. Reducing SDS-PAGE resolved A. farnesiana pollen proteins were transferred to PVDF membrane. After blocking, membrane strips were kept for $3 \mathrm{~h}$ at room temperature with a mix of $100 \mu \mathrm{L}$ of pooled sera $(1: 5 \mathrm{v} / \mathrm{v})$ (from patients 2, 7, 21, 24, and 36) which were preincubated with pollen extracts from $P$. juliflora, S. kali, A. retroflexus, $C$. album, and K. scoparia, as well as BSA (as negative control).

\section{Results}

3.1. Patients. Forty-two patients, 20 males and 22 females (mean age, $33.60 \pm 14.47$ years; age range $10-70$ years), were included in the study (Table 1). All patients suffered from respiratory allergies and seasonal rhinitis without asthma. The patients were all positive by skin prick test with $A$. farnesiana, P. juliflora, S. kali, A. retroflexus, C. album, and K. scoparia extracts (Table 1). A serum pool of 5 nonallergic subjects was used as a negative control.

3.2. Skin Prick Test. Mean diameters of positive wheal sizes were A. farnesiana: $6.69 \pm 1.17 \mathrm{~mm}$, P. juliflora: $7.57 \pm 1.50 \mathrm{~mm}$, S. kali: $9.95 \pm 2.81 \mathrm{~mm}$, A. retroflexus: $9.74 \pm 4.79 \mathrm{~mm}$,
C. album: $10.19 \pm 3.79 \mathrm{~mm}$, and K. scoparia: $8.9 \pm 3.70 \mathrm{~mm}$. Positive correlation coefficients were attained between the A. farnesiana and P. juliflora $(r=0.64, P<0.01), A$. farnesiana and $S$. kali $(r=0.07, P=0.6)$, A. farnesiana and $A$. retroflexus ( $r=0.1, P=0.4)$, A. farnesiana and $C$. album ( $r=0.06, P=0.6$ ), and A. farnesiana and $K$. scoparia $(r=0.007, P=0.9)$ pollen extracts for wheal diameter on the SPT (ANOVA procedure).

3.3. Protein and Allergenic Profile. The protein composition of A. farnesiana extract was analyzed by Coomassie Brilliant Blue staining (Figure 1(a)). The reducing SDS-PAGE separation of the pollen extract showed several resolved protein bands in the A. farnesiana extract with molecular weights in the range of approximately 12 to $85 \mathrm{kDa}$. The most prominent bands had MWs of approximately 50, 66, and $85 \mathrm{kDa}$. Other predominant bands were identified at $12,15,20,23,28$, 37 , and $45 \mathrm{kDa}$. Nonreducing SDS-PAGE of Acacia pollen extract showed eight prominent protein bands with estimated molecular weights between 15 and $66 \mathrm{kDa}$ (Figure 1(a)).

$\mathrm{IgE}$ reactivity of the separated protein bands from the electrophoresis of Acacia pollen extract was determined via immunoblotting assays. Specific IgE binding fractions probed with sera from all forty-two allergic patients are shown in Figure 1(b). The results showed several IgE reactive bands ranging from about 12 to $85 \mathrm{kDa}$. Figure $1(\mathrm{~b})$ shows the apparent MW of each protein fraction and the prevalence of each one among all forty-two allergic patients. The most frequent IgE reactive bands among the patients' sera were approximately 66 and $85 \mathrm{kDa}$. However, there were other IgE reactive protein bands among patients' sera with molecular weights $15,20,23,28,39,45$, and $50 \mathrm{kDa}$ (Figure $1(\mathrm{~b})$ ). No band was detected when a negative control serum pool was assayed.

3.4. Specific IgE Levels and Inhibition ELISA. The sera of forty-two allergic patients were evaluated for specific IgE binding to total Acacia pollen extract. All allergic patients had detectable specific IgE levels to the total extract of Acacia pollen (Table 1). These results are consistent with those 
TABLE 1: Clinical characteristics, total and specific IgE values, and skin reactivity of allergic patients.

\begin{tabular}{|c|c|c|c|c|c|c|c|c|c|c|}
\hline \multirow[b]{2}{*}{$\begin{array}{l}\text { Sample } \\
\text { number }\end{array}$} & \multirow{2}{*}{$\begin{array}{c}\text { Age } \\
\text { (years)/sex }\end{array}$} & \multirow{2}{*}{ Symptoms ${ }^{2}$} & \multirow{2}{*}{$\begin{array}{c}\text { Acacia } \\
\text { specific } \\
\operatorname{IgE}^{3}(\mathrm{OD})\end{array}$} & \multirow{2}{*}{$\begin{array}{l}\text { Total IgE } \\
\text { (IU/mL) }\end{array}$} & \multicolumn{6}{|c|}{ Diameters $(\mathrm{mm})$ of the papules obtained by prick test ${ }^{4}$} \\
\hline & & & & & $\begin{array}{c}\text { A. } \\
\text { farnesiana }\end{array}$ & P. juliflora & S. kali & $\begin{array}{c}\text { A. } \\
\text { retroflexus }\end{array}$ & C. album & K. scoparia \\
\hline \multicolumn{11}{|l|}{ Patients } \\
\hline 1 & $34 / \mathrm{M}$ & $\mathrm{L}, \mathrm{N}, \mathrm{E}$ & 0.9 & 181 & 7 & 5 & 8 & 9 & 10 & 9 \\
\hline 2 & $41 / \mathrm{M}$ & $\mathrm{N}, \mathrm{E}$ & 2.33 & 453 & 8 & 9 & 10 & 30 & 11 & 11 \\
\hline 3 & $39 / \mathrm{F}$ & $\mathrm{L}, \mathrm{N}$ & 2.71 & 156 & 5 & 7 & 16 & 11 & 10 & 9 \\
\hline 4 & $14 / \mathrm{F}$ & $\mathrm{L}, \mathrm{N}, \mathrm{E}$ & 1.11 & 165 & 7 & 9 & 7 & 5 & 14 & 11 \\
\hline 5 & $12 / \mathrm{M}$ & $\mathrm{L}, \mathrm{N}, \mathrm{E}$ & 1.10 & 123 & 5 & 6 & 4 & 3 & 2 & 0 \\
\hline 6 & $10 / \mathrm{M}$ & $\mathrm{L}, \mathrm{N}, \mathrm{E}$ & 1.19 & 313 & 6 & 5 & 10 & 10 & 9 & 8 \\
\hline 7 & $29 / \mathrm{F}$ & $\mathrm{L}, \mathrm{N}, \mathrm{E}$ & 1.89 & 345 & 7 & 8 & 8 & 7 & 11 & 5 \\
\hline 8 & $43 / \mathrm{F}$ & $\mathrm{N}, \mathrm{E}$ & 1.98 & 234 & 6 & 7 & 10 & 12 & 11 & 12 \\
\hline 9 & $21 / \mathrm{M}$ & $\mathrm{N}, \mathrm{E}$ & 2.07 & 381 & 7 & 9 & 10 & 10 & 12 & 11 \\
\hline 10 & $26 / \mathrm{F}$ & $\mathrm{N}, \mathrm{E}$ & 0.89 & 225 & 5 & 7 & 10 & 9 & 10 & 11 \\
\hline 11 & $26 / \mathrm{F}$ & $\mathrm{L}, \mathrm{N}, \mathrm{E}$ & 1.02 & 468 & 5 & 5 & 10 & 7 & 12 & 8 \\
\hline 12 & $23 / \mathrm{F}$ & $\mathrm{L}, \mathrm{N}, \mathrm{E}$ & 0.85 & 265 & 6 & 8 & 13 & 9 & 10 & 10 \\
\hline 13 & $30 / \mathrm{M}$ & $\mathrm{N}, \mathrm{E}$ & 1.63 & 167 & 7 & 7 & 10 & 7 & 8 & 9 \\
\hline 14 & $21 / F$ & $\mathrm{~L}, \mathrm{~N}, \mathrm{E}$ & 1.50 & 275 & 7 & 9 & 10 & 10 & 11 & 12 \\
\hline 15 & $70 / \mathrm{M}$ & $\mathrm{L}, \mathrm{N}, \mathrm{E}$ & 1.97 & 187 & 6 & 6 & 12 & 11 & 15 & 10 \\
\hline 16 & $43 / \mathrm{F}$ & $\mathrm{N}, \mathrm{E}$ & 1.85 & 212 & 8 & 7 & 12 & 8 & 11 & 10 \\
\hline 17 & $32 / \mathrm{F}$ & $\mathrm{L}, \mathrm{N}, \mathrm{E}$ & 1.94 & 250 & 6 & 8 & 10 & 11 & 13 & 15 \\
\hline 18 & $46 / \mathrm{F}$ & $\mathrm{L}, \mathrm{N}, \mathrm{E}$ & 1.52 & 261 & 5 & 7 & 10 & 7 & 9 & 10 \\
\hline 19 & $34 / \mathrm{F}$ & $\mathrm{N}, \mathrm{E}$ & 1.42 & 301 & 5 & 6 & 5 & 5 & 4 & 0 \\
\hline 20 & $13 / \mathrm{M}$ & $\mathrm{N}, \mathrm{E}$ & 2.01 & 463 & 8 & 9 & 12 & 5 & 8 & 6 \\
\hline 21 & $22 / \mathrm{M}$ & $\mathrm{N}$ & 2.21 & 280 & 9 & 8 & 8 & 8 & 6 & 7 \\
\hline 22 & $17 / \mathrm{F}$ & $\mathrm{L}, \mathrm{N}, \mathrm{E}$ & 2.02 & 302 & 8 & 10 & 8 & 7 & 5 & 5 \\
\hline 23 & $61 / \mathrm{M}$ & $\mathrm{N}$ & 1.04 & 186 & 5 & 6 & 9 & 10 & 9 & 10 \\
\hline 24 & $66 / \mathrm{M}$ & $\mathrm{L}, \mathrm{N}, \mathrm{E}$ & 2.10 & 293 & 10 & 12 & 9 & 8 & 6 & 7 \\
\hline 25 & $10 / \mathrm{M}$ & $\mathrm{L}, \mathrm{N}$ & 1.83 & 220 & 8 & 7 & 4 & 4 & 5 & 0 \\
\hline 26 & $33 / \mathrm{M}$ & $\mathrm{L}, \mathrm{N}$ & 1.55 & 214 & 7 & 7 & 10 & 10 & 9 & 9 \\
\hline 27 & $40 / \mathrm{F}$ & $\mathrm{L}, \mathrm{N}$ & 1.65 & 122 & 5 & 5 & 10 & 9 & 11 & 9 \\
\hline 28 & $53 / \mathrm{F}$ & $\mathrm{N}$ & 1.87 & 200 & 7 & 9 & 8 & 8 & 9 & 10 \\
\hline 29 & $46 / \mathrm{M}$ & $\mathrm{N}, \mathrm{E}$ & 1.91 & 192 & 7 & 6 & 10 & 9 & 10 & 10 \\
\hline 30 & $43 / \mathrm{M}$ & $\mathrm{L}, \mathrm{N}, \mathrm{E}$ & 2.15 & 284 & 7 & 7 & 8 & 7 & 9 & 5 \\
\hline 31 & $19 / \mathrm{F}$ & $\mathrm{L}, \mathrm{N}, \mathrm{E}$ & 1.92 & 187 & 8 & 7 & 9 & 8 & 9 & 6 \\
\hline 32 & $36 / F$ & $\mathrm{~L}, \mathrm{~N}, \mathrm{E}$ & 1.89 & 156 & 7 & 8 & 15 & 23 & 25 & 15 \\
\hline 33 & $19 / \mathrm{F}$ & $\mathrm{L}, \mathrm{N}, \mathrm{E}$ & 1.29 & 360 & 7 & 10 & 10 & 9 & 10 & 10 \\
\hline 34 & $37 / F$ & $\mathrm{~N}, \mathrm{E}$ & 1.93 & 267 & 7 & 8 & 12 & 12 & 11 & 11 \\
\hline 35 & $32 / \mathrm{M}$ & $\mathrm{N}, \mathrm{E}$ & 1.87 & 228 & 7 & 9 & 8 & 9 & 10 & 10 \\
\hline 36 & $51 / \mathrm{M}$ & $\mathrm{N}, \mathrm{E}$ & 2.11 & 358 & 7 & 8 & 14 & 13 & 11 & 12 \\
\hline 37 & $28 / \mathrm{F}$ & $\mathrm{L}, \mathrm{N}, \mathrm{E}$ & 1.60 & 294 & 6 & 8 & 12 & 11 & 11 & 10 \\
\hline 38 & $29 / \mathrm{M}$ & $\mathrm{L}, \mathrm{N}, \mathrm{E}$ & 1.96 & 304 & 6 & 7 & 18 & 16 & 18 & 14 \\
\hline 39 & $44 / \mathrm{M}$ & $\mathrm{N}, \mathrm{E}$ & 2.02 & 418 & 6 & 8 & 10 & 8 & 9 & 9 \\
\hline 40 & $40 / \mathrm{M}$ & $\mathrm{N}, \mathrm{E}$ & 2.12 & 315 & 8 & 9 & 13 & 18 & 16 & 17 \\
\hline 41 & $38 / \mathrm{F}$ & $\mathrm{N}$ & 2.09 & 480 & 7 & 8 & 8 & 9 & 9 & 6 \\
\hline 42 & $40 / \mathrm{F}$ & $\mathrm{N}, \mathrm{E}$ & 1.72 & 257 & 6 & 7 & 8 & 7 & 9 & 5 \\
\hline \multicolumn{11}{|l|}{ Controls } \\
\hline 44 & $28 / \mathrm{F}$ & - & 0.09 & 32 & 0 & 0 & 0 & 0 & 0 & 0 \\
\hline 45 & $45 / \mathrm{F}$ & - & 0.05 & 12 & $\mathbf{0}$ & $\mathbf{0}$ & $\mathbf{0}$ & 0 & $\mathbf{0}$ & $\mathbf{0}$ \\
\hline 46 & $32 / \mathrm{M}$ & - & 0.06 & 88 & $\mathbf{0}$ & $\mathbf{0}$ & $\mathbf{0}$ & $\mathbf{0}$ & $\mathbf{0}$ & $\mathbf{0}$ \\
\hline 47 & $38 / \mathrm{M}$ & - & 0.10 & 65 & $\mathbf{0}$ & $\mathbf{0}$ & $\mathbf{0}$ & 0 & $\mathbf{0}$ & 0 \\
\hline 48 & $22 / \mathrm{M}$ & - & 0.05 & 22 & 0 & $\mathbf{0}$ & $\mathbf{0}$ & $\mathbf{0}$ & 0 & $\mathbf{0}$ \\
\hline
\end{tabular}

${ }^{1} \mathrm{M}$ : male; F: female.

${ }^{2}$ L: lungs symptoms (breathlessness, tight chest, cough, wheeze); N: nose symptoms (sneezing, runny, blocked); E: eyes symptoms (itching, dry).

${ }^{3}$ Levels of specific IgE to $A$. retroflexus pollen extract by ELISA (optical density at $450 \mathrm{~nm}$ ).

${ }^{4}$ The mean wheal diameters are displayed in $\mathrm{mm}$. Histamine diphosphate $(10 \mathrm{mg} / \mathrm{mL})$ positive control; glycerin-negative control. 


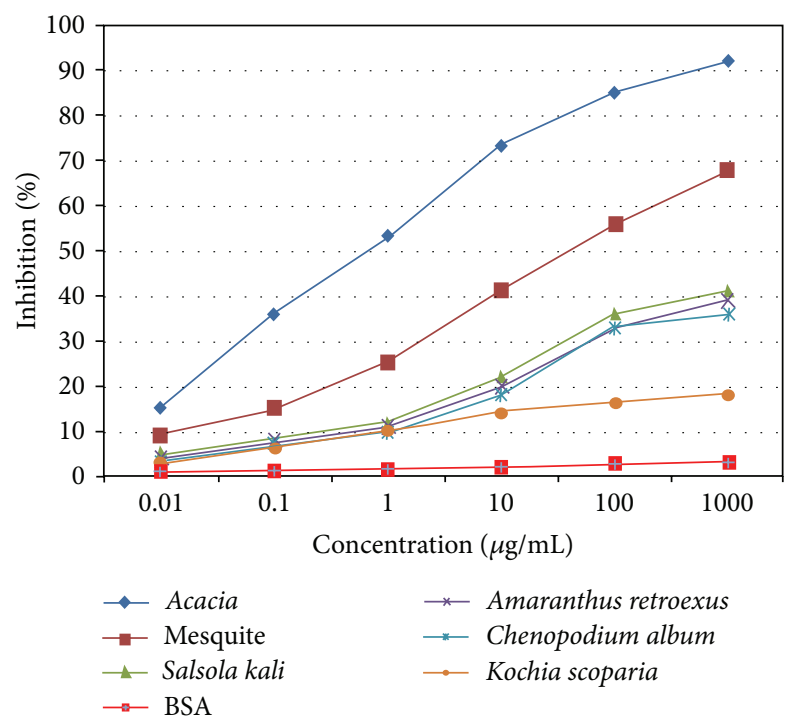

FIgure 2: Inhibition of IgE binding to Acacia pollen extract by ELISA using pollen extract from the most allergenic plants, mesquite, S. kali, A. retroflexus, C. album, and K. scoparia. Control experiments were performed with BSA.

obtained in the IgE-immunoblotting assays using the pollen extract of Acacia (Figure 1(b)). To investigate cross-reactivity and allergenic potency among Acacia and P. juliflora, S. kali, A. retroflexus, C. album, and K. scoparia, ELISA inhibition with their extracts was done (Figure 2). Almost complete inhibition was attained with $100 \mu \mathrm{g} / \mathrm{mL}$ of Acacia pollen extract as positive control. Preincubation of pooled serum with high concentration $(1000 \mu \mathrm{g} / \mathrm{mL})$ of $P$. juliflora revealed significant inhibition of IgE binding to allergenic proteins of A. farnesiana pollen extract (68\%) (Figure 2).

3.5. Immunoblot Inhibition Assays. In order to evaluate the IgE cross-reactivity between Acacia and five other allergenic pollen extracts, an immunoblot inhibition was carried out with the Acacia pollen extract as the solid phase. As shown in Figure 3, IgE reactivity to most of the allergenic proteins of Acacia pollen was inhibited when the Acacia pollen extract was used as an inhibitor (positive control Lane 2). Complete inhibition of IgE binding to $15,23,45$, and $50 \mathrm{kDa}$ components of Acacia extract occurred when the sera were preincubated with $P$. juliflora extract at $70 \mu \mathrm{g} / \mathrm{mL}$. Meanwhile, the three bands at about 28,66 , and $85 \mathrm{kDa}$ were partially inhibited. However, when S. kali, A. retroflexus, C. album, and K. scoparia pollen extracts were used as inhibitors, the 20,39, 45 , and $50 \mathrm{kDa}$ bands were completely inhibited, whereas the $15,23,28,66$, and $85 \mathrm{kDa}$ were not inhibited (Figure 3).

\section{Discussion}

Acacia is one of the major trees throughout arid and semiarid areas of Iran and neighboring countries along the Persian Gulf and the Sea of Oman [2, 16]. SDS-PAGE revealed several bands from the Acacia pollen extract with estimated MWs from $12 \mathrm{kDa}$ to $85 \mathrm{kDa}$ (Figure 1(a)). Among those bands, six IgE binding protein fractions with apparent MWs

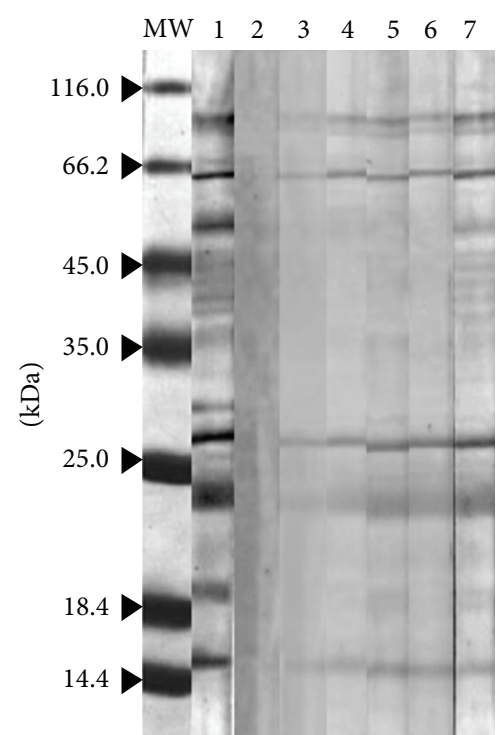

FIGURE 3: Immunoblotting inhibition assays. Lane MW, molecular weight marker (Fermentas, Lithuania). Lane 1, Acacia protein strip incubated with pooled serum without inhibitor (negative control). Lane 2, Acacia protein strip incubated with pooled serum containing $70 \mu \mathrm{g}$ of Acacia pollen extract as inhibitor (positive control). Lane 3 , Acacia protein strip incubated with pooled serum containing $70 \mu \mathrm{g}$ P. juliflora as inhibitor. Lane 4, Acacia protein strip incubated with pooled serum containing $70 \mu \mathrm{g}$ S. kali as inhibitor. Lane 5, Acacia protein strip incubated with pooled serum containing $70 \mu \mathrm{g}$ A. retroflexus as inhibitor. Lane 6, Acacia protein strip incubated with pooled serum containing $70 \mu \mathrm{g}$ C. album as inhibitor. Lane 7 , Acacia protein strip incubated with pooled serum containing $70 \mu \mathrm{g}$ K. scoparia as inhibitor.

of $85,66,39,45,28,23$, and $15 \mathrm{kDa}$ were detected from the blot (Figure 1(b)). Moreover, the results of SDS-PAGE showed relative similarity patterns of migration by protein components of the five selected pollens, mainly those of 15$85 \mathrm{kDa}$ (data not shown). In previous studies the proteins with apparent MWs $39,45,66$, and $85 \mathrm{kDa}$ have been the most allergenic proteins in the selected allergenic weeds in this study [10, 17-19].

In the current study, the immunoblot analysis with individual patient's serum demonstrated diverse IgE reactivity with seven proteins of $15,23,28,39,45,66$, and $85 \mathrm{kDa}$ as major IgE binding components. However, immunoblots showed that in the allergenic profile of Acacia pollen extract the proteins with apparent MWs of 66 and $85 \mathrm{kDa}$ are the major reactive proteins.

The results of SDS-PAGE revealed that the overall pattern of migration of Acacia pollen proteins changed under both reducing conditions. It was thus suggested that probable cysteine residues of the pollen proteins may be associated with interchain disulfide bonds. In previous studies, it was demonstrated that some proteins in pollen extract such as methionine synthase of S. kali or A. retroflexus were partially degraded into two fragments with approximate MWs of 45 and $39 \mathrm{kDa}[19,20]$. Taken together, these observations suggested that some proteins in Acacia pollen extract are 
susceptible to degradation as a result of proteolysis or exposure to a reducing condition. Moreover, it is possible that the number or size of the products of these proteins' degradation depends on the conditions of pollen extract preparation and storage. Nevertheless, additional studies are required to elucidate the patterns of degradation and the number and the size of cleavage products.

Cross-reactivity among Acacia pollen components with Lolium perenne pollen allergens has been described [8]

Several studies reported that proteins with apparent MWs of 45 and $66 \mathrm{kDa}$ are allergenic in the pollen extracts of mesquite [18] and the selected member of the Chenopodiaceae family $[10,19]$. The results of immunoblotting inhibition revealed that the IgE binding reactivity of the allergenic proteins with 12, 20,39, and 45 from the A. farnesiana pollen extract was partially inhibited by all four pollen extracts and also partially with $K$. scoparia pollen extract. As shown in Figure 3, IgE reactivity to most of the allergenic proteins of A. farnesiana pollen was inhibited when the P. juliflora pollen extract was used as an inhibitor. This indicates a significant IgE cross-reactivity between the two pollens and is also in line with the results of the SPTs (see below).

The results of SPTs indicated highly significant correlations between the wheal diameters from the A. farnesiana pollen extract and those from $P$. juliflora pollen extracts $(r=$ $0.64, P<0.01)$. These results suggest an extensive $\operatorname{IgE}$ cross-reactivity among these pollens and are concurrent with the results of immunoblotting and inhibition experiments. These results collectively suggest that in these pollen extracts, protein components with MWs range 45 to $66 \mathrm{kDa}$ may play a greater role in cross-reactivity compared to others. Earlier studies had also indicated one of the most allergenic proteins of $S$. kali pollen, named Sal k 1, with a MW of $40-43 \mathrm{kDa}[21$, 22]. Sal $k 1$ displayed pectin methylesterase (PME) properties and is considered a major allergen of $S$. kali pollen [14, 21, 22].

In general, the knowledge of pollen cross-reactivity is crucial for diagnostics as well as formulation of immunotherapy vaccines. Cross-reactivity among pollens belonging to the same genus and/or different genera has been demonstrated earlier [23]. Some cross-reactive proteins have been genetically engineered and are found to have potential for use in immunotherapy [24].

Another dominant IgE binding protein band with an estimated MW of $15 \mathrm{kDa}$ was also detected by immunoblotting of Acacia pollen extract (Figure 1(b)). Earlier, the allergens belonging to the profilin family with apparent MWs of 14 to $15 \mathrm{kDa}$ were found from S. kali (Sal k 4), A. retroflexus (Ama r 2), and C. album (Che a 2) pollens [25-27]. It may be that the $15 \mathrm{kDa}$ - protein of Acacia pollen is homologous with the $15-\mathrm{kDa}$ IgE reactive band in these plants. However, further studies are required to prove the nature of this allergenic protein of Acacia pollen.

\section{Conclusion}

In conclusion, A. farnesiana pollen is a potent allergen source with several IgE binding components. The observations altogether suggest a close allergenic relationship between
Acacia and mesquite. Regarding the extensive cross-reactivity between these two trees and the abundance of them in tropical and subtropical regions, identification and production of the recombinant forms of common allergens of these pollens may lead to the exploration of new guidelines for diagnostic, therapeutic, and preventive purposes. Efforts are now underway to clone cDNAs encoding allergenic crossreactive proteins from Acacia pollen.

\section{Disclosure}

This paper is issued from thesis of Mr. Shams.

\section{Conflict of Interests}

The authors declare that there is no conflict of interests regarding the publication of this paper.

\section{Acknowledgments}

Financial support was provided by Ahvaz Jundishapur University of Medical Sciences (Grant no. CRC-9108). The authors would like to thank Dr. Afshin Arti, University of Toronto, for his critical reading of the paper.

\section{References}

[1] M. Caccavari and E. Dome, "An account of morphological and structural characterization of American Mimosoideae pollen. Part I: tribe Acacieae," Palynology, vol. 24, no. 1, pp. 231-248, 2000.

[2] M. A. Assarehzadegan, A. Shakurnia, and A. Amini, “The most common aeroallergens in a tropical region in Southwestern Iran," World Allergy Organization Journal, vol. 6, article 7, 2013.

[3] R. Ariano, R. C. Panzani, and J. Amedeo, "Pollen allergy to mimosa (Acacia floribunda) in a Mediterranean area: an occupational disease," Annals of Allergy, vol. 66, no. 3, pp. 253256, 1991.

[4] A. Bener, W. Safa, S. Abdulhalik, and G. G. Lestringant, "An analysis of skin prick test reactions in asthmatics in a hot climate and desert environment," Allergie et Immunologie, vol. 34, no. 8, pp. 281-286, 2002.

[5] M. Fereidouni, R. Farid Hossini, F. Jabbari Azad, M. A. Assarehzadegan, and A. Varasteh, "Skin prick test reactivity to common aeroallergens among allergic rhinitis patients in Iran," Allergologia et Immunopathologia, vol. 37, no. 2, pp. 73-93, 2009.

[6] F. A. Suliaman, W. F. Holmes, S. Kwick, F. Khouri, and R. Ratard, "Pattern of immediate type hypersensitivity reactions in the Eastern Province, Saudi Arabia," Annals of Allergy, Asthma \& Immunology, vol. 78, no. 4, pp. 415-418, 1997.

[7] M. A. Assarehzadegan, A. H. Shakurnia, and A. Amini, "Sensitization to common aeroallergens among asthmatic patients in a tropical region affected by dust storm," Journal of Medical Sciences, vol. 13, no. 7, pp. 592-597, 2013.

[8] B. J. Howlett, D. J. Hill, and R. B. Knox, "Cross-reactivity between Acacia (wattle) and rye grass pollen allergens. Detection of allergens in Acacia (wattle) pollen," Clinical Allergy, vol. 12, no. 3, pp. 259-268, 1982.

[9] A. Al-Dowaisan, N. Fakim, M. R. Khan et al., "Salsola pollen as a predominant cause of respiratory allergies in Kuwait," Annals 
of Allergy, Asthma and Immunology, vol. 92, no. 2, pp. 262-267, 2004.

[10] M. A. Assarehzadegan, M. Sankin, F. Jabbari, R. Noorbakhsh, and A. Varasteh, "Allergy to Salsola kali in a Salsola incanescensrich area: role of extensive cross allergenicity," Allergology International, vol. 58, no. 2, pp. 261-266, 2009.

[11] J. Mandal, I. Roy, S. Chatterjee, and S. Gupta-Bhattacharya, "Aerobiological investigation and in vitro studies of pollen grains from 2 dominant avenue trees in Kolkata, India," Journal of Investigational Allergology and Clinical Immunology, vol. 18, no. 1, pp. 22-30, 2008.

[12] R. Valenta and D. Kraft, "From allergen structure to new forms of allergen-specific immunotherapy," Current Opinion in Immunology, vol. 14, no. 6, pp. 718-727, 2002.

[13] M. M. Bradford, "A rapid and sensitive method for the quantitation of microgram quantities of protein utilizing the principle of protein dye binding," Analytical Biochemistry, vol. 72, no. 1-2, pp. 248-254, 1976.

[14] M. A. Assarehzadegan, M. Sankian, F. Jabbari, M. Tehrani, and A. Varasteh, "Expression of the recombinant major allergen of Salsola kali pollen (Sal k 1) and comparison with its lowimmunoglobulin E-binding mutant," Allergology International, vol. 59, no. 2, pp. 213-222, 2010.

[15] U. K. Laemmli, "Cleavage of structural proteins during the assembly of the head of bacteriophage T4," Nature, vol. 227, no. 5259, pp. 680-685, 1970.

[16] S. Irian, A. Majd, A. Hoseinizadeh, and P. Jounobi, "A study on the allergenicity and ontogeny of Acacia farnesiana pollen grains in guinea pigs," Aerobiologia, vol. 29, no. 1, pp. 21-29, 2013.

[17] A. Dhyani, N. Arora, S. N. Gaur, V. K. Jain, S. Sridhara, and B. P. Singh, "Analysis of IgE binding proteins of mesquite (Prosopis juliflora) pollen and cross-reactivity with predominant tree pollens," Immunobiology, vol. 211, no. 9, pp. 733-740, 2006.

[18] A. Dhyani, B. P. Singh, N. Arora, V. K. Jain, and S. Sridhara, "A clinically relevant major cross-reactive allergen from mesquite tree pollen," The European Journal of Clinical Investigation, vol. 38, no. 10, pp. 774-781, 2008.

[19] M. Tehrani, M. Sankian, M. A. Assarehzadegan, R. Falak, F. Jabbari, and A. Varasteh, "Immunochemical characterization of Amaranthus retroflexus pollen extract: extensive cross-reactive allergenic components among the four species of Amaranthaceae/Chenopodiaceae," Iranian Journal of Allergy, Asthma and Immunology, vol. 9, no. 2, pp. 87-95, 2010.

[20] M. A. Assarehzadegan, M. Sankian, F. Jabbari, M. Tehrani, R. Falak, and A. Varasteh, "Identification of methionine synthase (Sal k 3), as a novel allergen of Salsola kali pollen," Molecular Biology Reports, vol. 38, no. 1, pp. 65-73, 2011.

[21] R. Barderas, J. García-Sellés, G. Salamanca et al., "A pectin methylesterase as an allergenic marker for the sensitization to Russian thistle (Salsola kali) pollen," Clinical and Experimental Allergy, vol. 37, no. 7, pp. 1111-1119, 2007.

[22] J. Carnés, E. Fernández-Caldas, A. Marina et al., "Immunochemical characterization of Russian thistle (Salsola kali) pollen extracts. Purification of the allergen Sal k 1," Allergy, vol. 58, no. 11, pp. 1152-1156, 2003.

[23] R. W. Weber, "Cross-reactivity of pollen allergens," Current Allergy and Asthma Reports, vol. 4, no. 5, pp. 401-408, 2004.

[24] V. Niederberger, F. Horak, S. Vrtala et al., "Vaccination with genetically engineered allergens prevents progression of allergic disease," Proceedings of the National Academy of Sciences of the United States of America, vol. 101, no. 2, pp. 14677-14682, 2004.
[25] A. Amini, M. Sankian, M. A. Assarehzadegan, F. Vahedi, and A. Varasteh, "Chenopodium album pollen profilin (Che a 2): homology modeling and evaluation of cross-reactivity with allergenic profilins based on predicted potential IgE epitopes and IgE reactivity analysis," Molecular Biology Reports, vol. 38, no. 4, pp. 2579-2587, 2011.

[26] M. A. Assarehzadegan, A. Amini, M. Sankian, M. Tehrani, F. Jabbari, and A. Varasteh, "Sal k 4, a new allergen of Salsola kali, is profilin: a predictive value of conserved conformational regions in cross-reactivity with other plant-derived profilins," Bioscience, Biotechnology and Biochemistry, vol. 74, no. 7, pp. 1441-1446, 2010.

[27] M. Tehrani, M. Sankian, M. A. Assarehzadegan et al., "Identification of a new allergen from amaranthus retroflexus pollen, ama r 2," Allergology International, vol. 60, no. 3, pp. 309-316, 2011. 


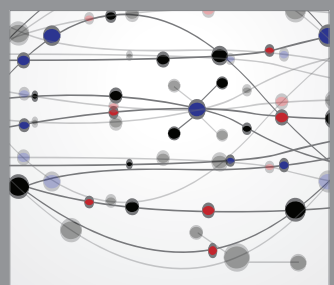

The Scientific World Journal
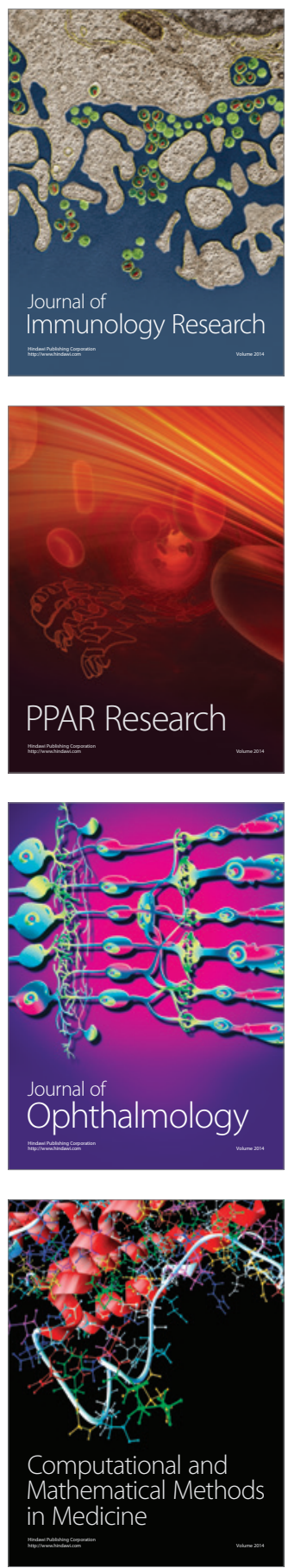

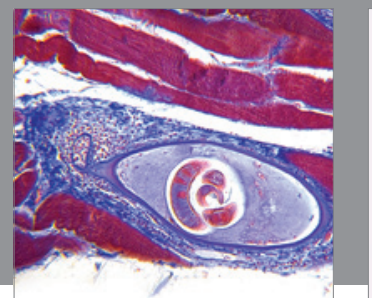

Gastroenterology

Research and Practice
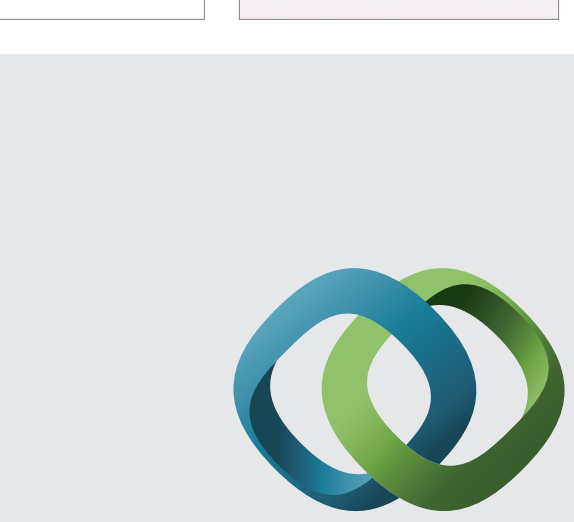

\section{Hindawi}

Submit your manuscripts at

http://www.hindawi.com
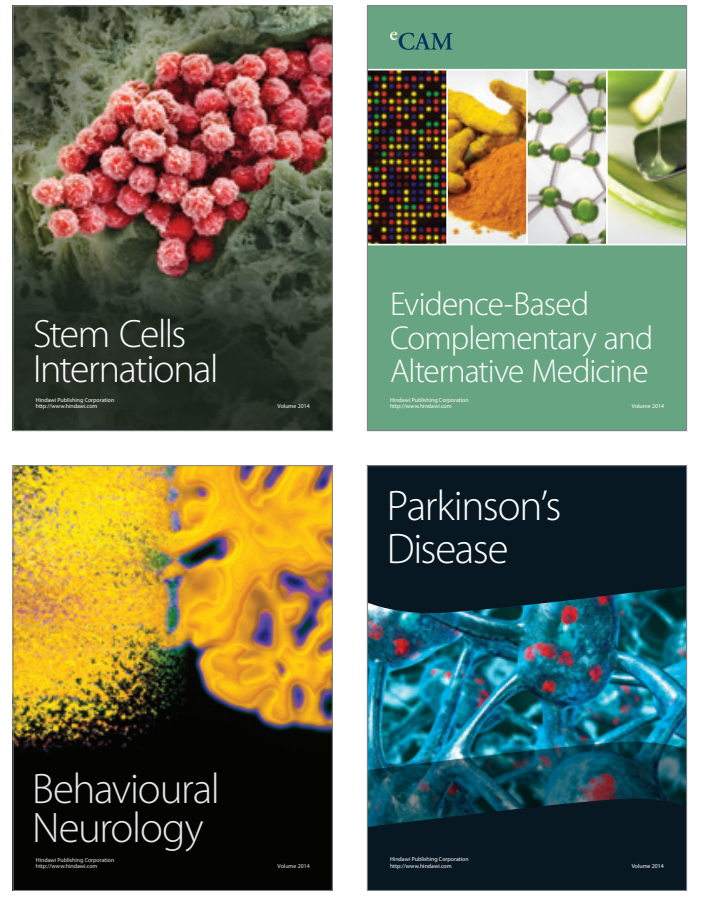
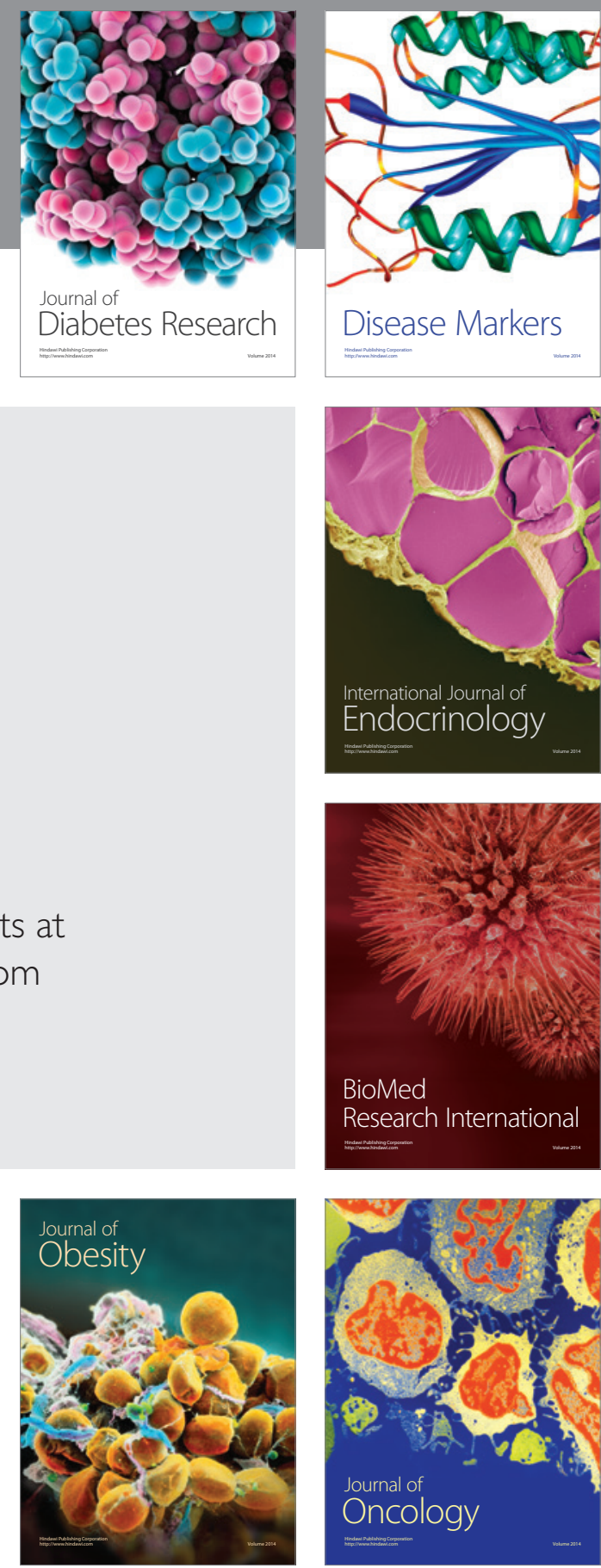

Disease Markers
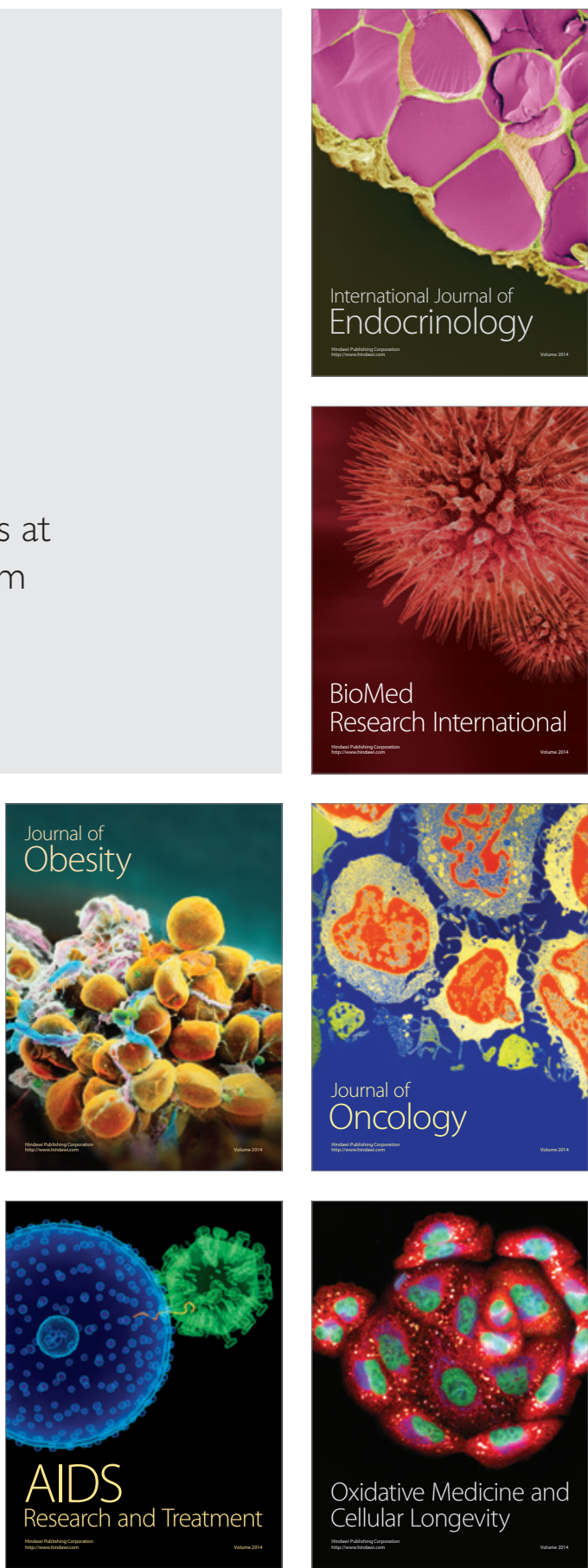